\title{
TCam-2 but not JKT-1 cells resemble seminoma in cell culture
}

\author{
D. Eckert • D. Nettersheim • L. C. Heukamp • \\ S. Kitazawa $\cdot$ K. Biermann $\cdot$ H. Schorle
}

Received: 9 August 2007 / Accepted: 20 September 2007

(C) Springer-Verlag 2007

\begin{abstract}
Of all malignancies diagnosed in men between 17 and 45 years of age, $60 \%$ are germ cell tumors (GCT). GCT arise from carcinoma in situ cells, which are thought to originate from a transformed fetal germ cell, the gonocyte. Seminoma together with embryonal carcinoma represent the most frequent subtypes of GCT. However, the nature of the molecular pathways involved in seminoma formation remains elusive. Therefore, analysis of appropriate cell culture systems is an important prerequisite for further understanding of the etiology of this tumor entity. Although several cell lines for embryonal carcinoma have been established and analyzed, so far only two cell lines from seminoma patients have been reported. In the present study, we have analyzed these seminoma cell lines (TCam-2 and JKT-1) and compared the gene-expression profiles with those of normal tissue and of seminoma and embryonal carcinoma
\end{abstract}

D. Eckert, D. Nettersheim, and L. C. Heukamp contributed equally to this work. This study was supported by DFG grants 503-6 and 503-7 to H.S.

Electronic supplementary material The online version of this article (doi:10.1007/s00441-007-0527-y) contains supplementary material, which is available to authorized users.

D. Eckert $\cdot$ D. Nettersheim $\cdot$ H. Schorle $(\bowtie)$

Abteilung für Entwicklungspathologie, Institut für Pathologie, Universität Bonn,

Sigmund-Freud-Strasse 25,

53127 Bonn, Germany

e-mail: hubert.schorle@ukb.uni-bonn.de

D. Nettersheim $\cdot$ L. C. Heukamp $\cdot$ K. Biermann Institut für Pathologie, Universität Bonn,

Bonn, Germany

S. Kitazawa

Division of Molecular Pathology, Department of Biomedical Informatics, Kobe University Graduate School of Medicine,

7-5-1 Kusunoki-cho, Chuo-ku, by using DNA Array technology. We have found that TCam-2 clusters with the group of classical seminoma, whereas JKT-1 clusters with the group of embryonal carcinoma. Using reverse transcription/polymerase chain reaction, Western blot, and immunohistochemistry, we have confirmed the seminoma-like nature of TCam-2, whereas JKT-1 lacks expression for most of the genes detectable in GCTs, thus making doubtful the germ cell nature of this cell line. The data represent the first genome-wide expression analysis of the two cell lines and comparison/clustering with subgroups of germ cell tumors. Only TCam-2 seems to represent a suitable in vitro model for seminoma.

Keywords Gonocyte $\cdot$ Neoplastic $\cdot$ Seminoma .

Germ cell tumor $\cdot$ Cell line

\section{Introduction}

The most abundant malignancies among male population between the ages of 17 and 45 years are germ cell tumors (GCTs; Adami et al. 1994). They comprise a heterogeneous group of neoplasms in terms of their histology, marker expression, and age of manifestation. First described by Skakkebaek in 1972, the common precursor lesion of all type II testicular GCTs (TGCT; Looijenga and Oosterhuis 2002), viz., the carcinoma in situ (CIS, TIN, IGCNU), arises from the transformation of a gonocyte (Skakkebaek 1972, 1978). In recent decades, the incidence of TGCT has increased annually by $3 \%-6 \%$ in the Caucasian population (Oosterhuis and Looijenga 2005). Of the Type II TGCTs, $50 \%$ manifest as pure seminomas, with uniform cells having a morphology similar to that of cells in CIS. Seminoma formation is believed to be the default pathway of type II TGCT, and the development of a non-seminoma 
requires the re-activation of pluripotency (Oosterhuis and Looijenga 2005). Interestingly, some seminomas eventually develop into non-seminomas, such as embryonal carcinoma, teratoma, yolk sac tumor, or choriocarcinoma. Marker genes developed for the diagnosis of seminomas include the marker of pluripotency OCT3/4, placental alkaline phosphatase (PLAP), the receptor tyrosine kinase KIT, and transcription factor AP- $2 \gamma$. Moreover, genome profiling studies by using various types of TGCTs have shed light on the molecular programs activated in these tumors (Skotheim et al. 2002, 2005; Okada et al. 2003; Sugimura et al. 2004; Almstrup et al. 2005a, b).

In order to improve our understanding of the biology of seminomas, the establishment and analysis of cell lines and animal models is mandatory. Although no animal models for seminoma are available to date, two groups have been successful in generating cell lines, namely JKT-1 and TCam-2 (Mizuno et al. 1993; Kinugawa et al. 1998), from seminoma patients. Whereas JKT-1 has been used frequently to study seminomas (Jo et al. 1999; Hatakeyama et al. 2004; Kobayashi et al. 2004; Roger et al. 2004, 2005; Shiraishi et al. 2005), TCam-2 has been utilized in a few cases only (Koshida et al. 2000; Kitazawa et al. 2006; Goddard et al. 2007). Since the original reports date from 1993 and 1998 respectively, the cell lines were analyzed with the marker sets known at that time. Further studies of these lines would therefore benefit from a thorough sideby-side analysis of the two cell lines with DNA Array techniques and up-to-date markers used for classification of GCT.

Here we have subjected both cell lines to geneexpression profiling and compared the obtained data with that obtained from normal testicular tissue, seminoma, and embryonal carcinoma. Using 41 probes indicative for GCT, we demonstrate that TCam-2 clusters to pure seminoma, whereas JKT-1 clusters to embryonal carcinoma. Further analysis with reverse transcription/polymerase chain reaction (RT-PCR), Western blot, and immunohistochemistry shows that TCam-2 expresses markers specifically found in seminoma, whereas JKT-1 lacks the expression of genes commonly detected in GCT.

\section{Materials and methods}

\section{Cell culture}

TCam-2 (obtained from Dr. Janet Shipley, Institute of Cancer Research, Sutton, England) was grown in RPMI plus $10 \%$ fetal calf serum (FCS), 1\% penicillin/streptomycin, $200 \mathrm{mM}$ glutamine. JKT1 cells (obtained from Dr. Michiko Fukuda, The Burnham Institute, La Jolla, Calif.) were grown in minimal essential medium (MEM) plus 10\% FCS, $1 \%$ penicillin/streptomycin, $200 \mathrm{mM}$ glutamine. The EC cell line 2102EP (obtained from Dr. F. Honecker, Hamburg University Medical Center, Department of Oncology/ Hematology, Hamburg, Germany) was grown in Dulbecco's modified Eagle's medium:F12 medium (1:1) plus 10\% FCS, $1 \%$ penicillin/streptomycin, $200 \mathrm{mM}$ glutamine. Knut1 ES cells derived in our laboratory were grown as published (Peitz et al. 2007). The cells were grown at $37^{\circ} \mathrm{C}$ and under $5 \% \mathrm{CO}_{2}$.

Testicular tissues

All fresh testicular tissue samples used for microarray analysis were obtained immediately after orchidectomy. Use of the tissue for scientific purposes was approved by an institutional regional committee for ethics. From patients with overt GCTs, three to five tumor samples and, if possible, macroscopically normal testicular tissue were excised, snap-frozen, and stored at $-80^{\circ}$ for RNA extraction. The orchidectomy samples were fixed in $4 \%$ phosphate-buffered formalin overnight at room temperature and embedded in paraffin. All frozen and paraffin-embedded tissues were stained by hematoxylin and eosin (H\&E) and by immunohistochemistry with PLAP antibody. All tumors were classified according to the World Health Organization classification of tumors based on their histology and assessment of tumor or IGCNU amount.

\section{RNA preparation}

To ensure sample purity, serial sections were taken, and the amount of target tissue estimated in the first and last section. Total RNA was extracted from normal testis $(n=3)$, seminomas $(n=5)$, and embryonal carcinomas $(n=3)$. RNA was extracted either with TRIzol (Invitrogen, Karlsruhe, Germany) or with RNAeasy (Qiagen, Hilden, Germany). RNA quality was assessed with a Agilent Bioanalyzer 2000 (Agilent Technologies, Palo Alto, Calif.), and only samples with an RIN value of $>8$ were used for further analysis.

Whole-genome gene-expression array analysis

Probe preparation, hybridization, image generation, and analysis were carried out according to the manufacturer's guidelines for the AB1700 Microarray system. Briefly, $2 \mu \mathrm{g}$ total RNA were translated in vitro and labeled with digoxigenin-11-uridine-5'-triphosphate (Roche Diagnostics, catalog no. 03359247910 ) and purified with the rt-IVT-Kit (Applied Biosystems). Digoxigenin-labeled cDNA probes were hybridized at $70^{\circ} \mathrm{C}$ for $16 \mathrm{~h}$ to the Whole Human Genome Survey Microarray V2.0 (Applied Biosystems) with 32,878 transcripts containing 60-mer DNA probes representing 29,098 genes. Visualization was achieved by incubating the microarray with an anti-digoxigenin alkaline 
phosphatase conjugate (Roche Diagnostics, catalog no. 11 093274 910). The Applied Biosystems 1700 Chemiluminescent Microarray Analyzer was employed to create and analyze images and to perform basic quality control and feature extraction.

\section{Bioinformatic data processing and analysis}

Using Bioconductor (http://www.bioconductor.org/docs/ faq/) R software and the AB1700 Data Analysis script (Yongming Andrew Sun, Applied Biosystems), all probe sets with FLAG $>5000$ were removed, and samples with more than $50 \%$ missing values were excluded from the analysis. Missing values were replaced with average signals from replicate arrays within the same subgroup. The data was normalized by quantile normalization and transformed to $\log 2$ scale.

\section{Western blot}

For protein analysis, we used the Mini-PROTEAN Electrophoresis Cell and Mini Trans-Blot system (BioRad, Munich, Germany). Protein was prepared by standard protocols and electrophoresed at $30 \mathrm{~mA}$ for $90 \mathrm{~min}$. Gels were blotted onto a polyvinylidene fluoride membrane in a BioRad blotting chamber overnight at $30 \mathrm{~V}$ at $4^{\circ} \mathrm{C}$ according to published protocols. After the membrane had been blocked in PBSTM (phosphate-buffered saline, 0.1\% $\mathrm{v} / \mathrm{v}$ Tween $20,5 \%$ low fat milk powder), it was incubated in primary antibodies (antibodies raised against: alpha fetoprotein [AFP], A008, 1:1,000; PLAP, 8A9, 1:50; Kit, A4502, 1:400; D2-40, M3619, 1:150; all from DAKO, Hamburg, Germany; AP-2 $\gamma$, 6E4/4, 1:200; from Upstate, USA, New York; Nanog, N-17, sc-30331, 1:200; OCT3/4, c-10, sc-5279, 1:200, all from Santa Cruz, Heidelberg, Germany) in PBSTM for $3 \mathrm{~h}$ at room temperature, followed by secondary antibodies (anti-rabbit-horseradish peroxidase [HRP], anti-goat-HRP, anti-mouse-HRP; all from DAKO, Hamburg, Germany) diluted 1:500 (except for Nanog, 1:2,000). Finally, the membrane was incubated in $2 \mathrm{ml}$ PierceSuper Signal West Pico chemiluminescent substrate (Perbio, Bonn, Germany, product no. 34080), and the signal was detected by using Kodak X-Ray film (Kodak, Germany).

\section{RT-PCR protocol}

RNA was isolated from cells and tissues by using TRIzol as described (Jager et al. 2003). For RT-PCR, $1 \mu \mathrm{g}$ DNAseI (NEB, Frankfurt, Germany)-digested RNA template was used. First-strand cDNA synthesis and PCR were performed according to manufacturer's manual (Invitrogen, Karlsruhe, Germany). PCR was carried out at $95^{\circ} \mathrm{C}$ for 4 min, followed by 30 cycles of $94^{\circ} \mathrm{C}$ for $30 \mathrm{~s}, 61^{\circ} \mathrm{C}$ for $30 \mathrm{~s}$, and $72^{\circ} \mathrm{C}$ for $30 \mathrm{~s}$, and finally at $72^{\circ} \mathrm{C}$ for $10 \mathrm{~min}$. The forward (F)and reverse (R) primers used were: AFP-F: $5^{\prime}$ A GCTTGGTGGTGGATGAAAC-3', AFP-R: 5'-CCСТCTTCAGCAAAGCAGAC-3'; AP- $2 \gamma-\mathrm{F}$ : 5'CCCACTGAGGTCTTCTGCTC-3', AP- $2 \gamma$-R: 5'-AGAG TCAC ATGAGCGGCTTT-3'; D-glyceraldehyde-3phosphate dehydrogenase [GAPDH]-F: 5'-TGGTATCGT GGAAGGACTCATG AC-3', GAPDH-R: 5'-ATGCCAG TGAGCTTCCCGTTCAGC-3'; MAGE-F: 5'-GAGCAG ACAGGCCAACCG-3', MAGE-R: 5'-CGGACTGCGTC TCAGGAA-3'; PLAP-F: 5'-GGTGAACCGCAACTG GTACT-3', PLAP-R: 5'-CCCACCTTGGCTGTAGT CAT3'; OCT4-F: 5'-CGAAAGAGAAAGCGAACCAG-3', OCT4-R: 5'-GCCGGT TACAGAACCACACT-3'; DAZLF: 5'-ATGTTAGGATGG ATGAAACTGAGATTA-3', DAZL-R: 5'-CCATGGAAATTTATCTGTGATTCTACT-3'; VASA-F: 5'-AGAAA GTAGTGATACTCAAGGACCAA3', VASA-R: 5'-TGA CAGAGATTAGCTTCTTC AAAAGT3'; BOULE-F: 5'-TATAAGGATAAGAAGCTGAA CATTGGT-3', BOULE-R: 5'-CGAAGTTACCTCTGGAG TATGAAAATA-3'; bone morphogenetic protein-2 [BMP-2]F: 5'-TCTGACTGACCGC GTTACTC-3', BMP-2-R: 5'TCTCTGTTTCAGGCCGAACA-3'.

\section{Immunohistochemistry}

The following primary antibodies were used for immunofluorescence: anti-AFP, diluted 1:200, A0008; anti-PLAP, diluted 1:50, 8A9; anti-ck18, diluted 1:50; anti-KIT, diluted 1:200, A4502; anti-D2-40, diluted 1:150, M3619 (all from DAKO); anti-AP-2 $\gamma$, diluted 1:200, H77; anti-NANOG, diluted 1:200, N-17; anti-Oct3/4, diluted 1:100, C-10 (all from Santa Cruz). Detection of primary antibodies was performed by using Alexa-488 goat anti-mouse, diluted 1:500; Alexa-488 donkey anti-goat, diluted 1:500; and Alexa-594 goat anti-rabbit, diluted 1:500 (all Invitrogen, Karlsruhe, Germany).

\section{Results}

Morphology and growth parameters

When comparing the morphology and growth characteristics of TCam-2 and JKT-1 with each other, several differences and a few similarities could be observed. After attachment to the culture flask surface, TCam-2 cells appeared polygonal and flat in shape, whereas JKT-1 cells are round (Fig. 1a,b). After a few days in culture, JKT-1 cells became polygonal in shape and looked similar to TCam-2, but still a few round cells remained (Fig. 1d). TCam-2 cells seemed to need either cell-cell-contact or a 


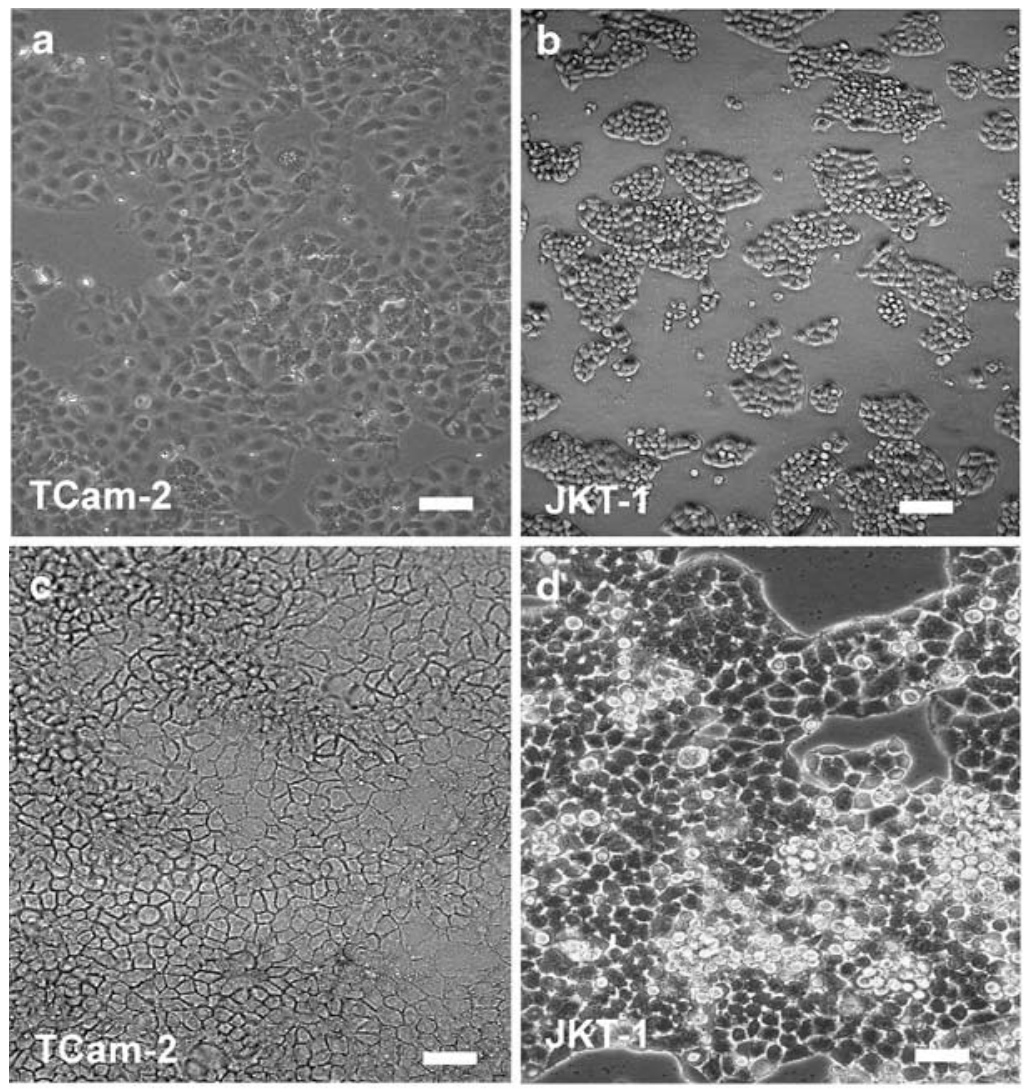

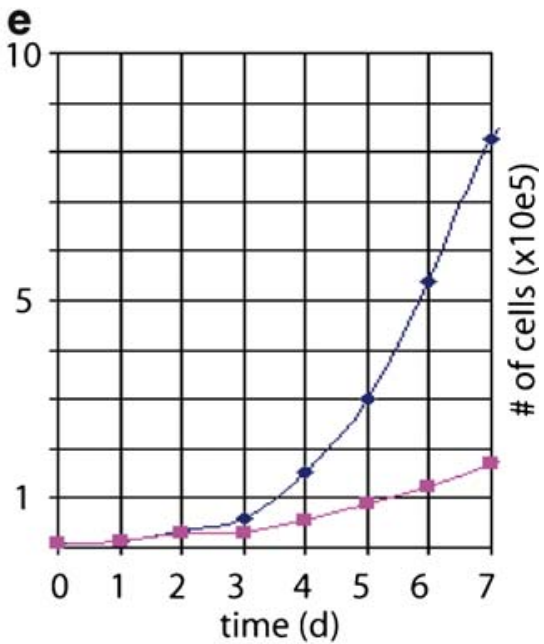

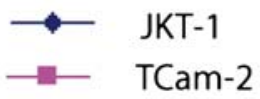

f

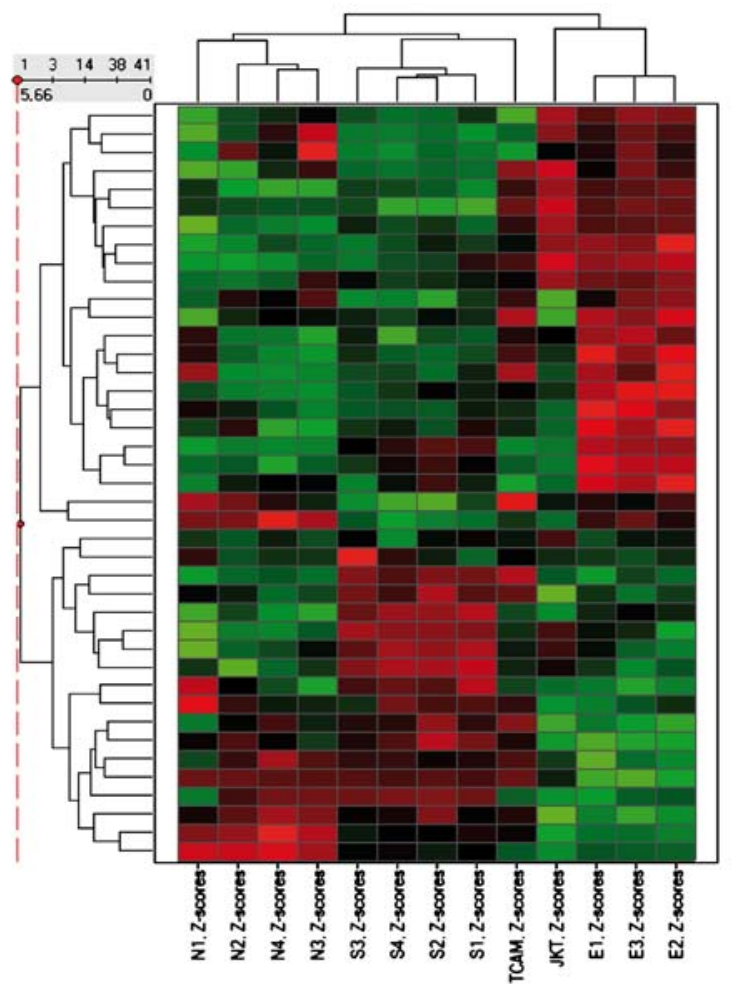

Fig. 1 a-d Comparison of TCam-2 (a, c) and JKT-1 (b, d) cells after 3 days $(\mathbf{a}, \mathbf{b})$ and 5 days $(\mathbf{c}, \mathbf{d})$ of culture. Bar $50 \mu \mathrm{m}$. e Growth curve of the cell lines. $\mathbf{f}$ Unsupervised hierarchical clustering of normal cells $(N$; $n=4)$, seminomas $(S ; n=4)$, embryonal carcinomas $(E ; n=3)$, and JKT-1 and TCam- 2 cell lines with 41 probes selected to differentiate between

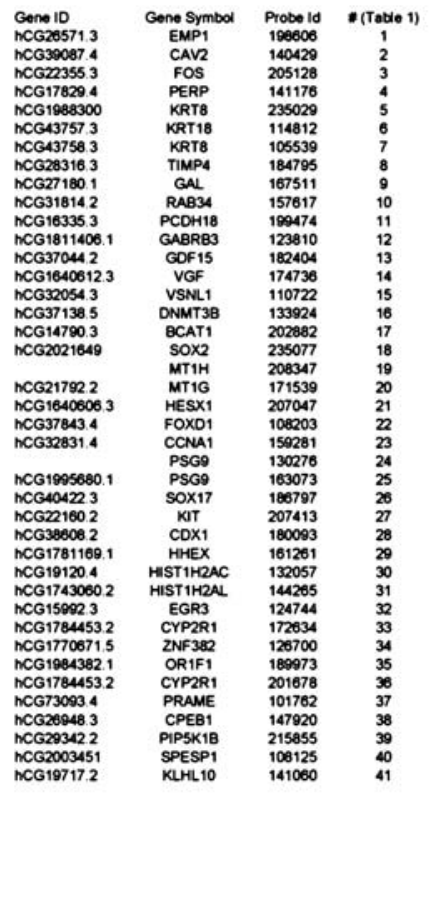

seminomas and embryonal carcinomas was performed to show similarity of Z-scores between the different tumour entities and cell lines entities. An unweighted averaged (UPGMA) method and Euclidian distance were used to generate the heat map in Spotfire; GeneID, Genesymbol, Probe $I D$, and number (\#) are given right (see also Table 1) 
certain cell density for optimal growth, because when the culture was initiated at low cell density, the cells required two to three times longer to reach exponential growth phase compared with a culture starting with high cell density. This property could not be detected when culturing JKT-1. After 5 days in culture, TCam-2 formed areas of high cell density in which cells were compressed and tightly clustered (Fig. 1c). JKT-1 cells grew in a looser formation (Fig. 1d). TCam-2 cells displayed higher adherence to the tissue culture surface compared with JKT-1 cells, suggest- ing a increased amount of desmosomes in TCam-2 cells. TCam-2 cells had larger nuclei and enlarged cytoplasm when compared with JKT-1 cells (see Supplemental Data $\mathrm{S} 1$ ). Both cell lines grew as a monolayer and displayed contact inhibition. To determine the doubling time, $1-2 \times 10^{4}$ cells were seeded onto $35-\mathrm{mm}$ cell culture dishes, and the cell number was determined every day (Fig. 1e). The calculated doubling times were $27 \mathrm{~h}$ for JKT-1 cells and $58 \mathrm{~h}$ for TCam-2 (see Supplemental Data S2). Hence, TCam-2 and JKT-1 displayed highly diverging basic growth characteristics in vitro.

Table 1 Probes selected for cluster analysis

\begin{tabular}{|c|c|c|c|c|c|c|c|}
\hline Number & Probe ID & Gene ID & Gene symbol & $\begin{array}{l}\text { Reference } \\
\text { (Skotheim } \\
\text { et al. 2005) }\end{array}$ & $\begin{array}{l}\text { Reference } \\
\text { (Korkola } \\
\text { et al. 2006) }\end{array}$ & $\begin{array}{l}\text { Reference } \\
\text { (Muller-Tidow } \\
\text { et al. 2003) }\end{array}$ & $\begin{array}{l}\text { Reference } \\
\text { (Biermann } \\
\text { et al. 2007) }\end{array}$ \\
\hline 1 & 198606 & hCG26571.3 & EMP1 & & & & $\mathrm{x}$ \\
\hline 2 & 140429 & hCG39087.4 & CAV2 & & & & $\mathrm{x}$ \\
\hline 3 & 205128 & hCG22355.3 & FOS & & & & $\mathrm{x}$ \\
\hline 4 & 141176 & hCG17829.4 & PERP & & & & $\mathrm{x}$ \\
\hline 5 & 235029 & hCG1988300 & KRT8 & & & & $\mathrm{x}$ \\
\hline 6 & 114812 & hCG43757.3 & KRT18 & $\mathrm{x}$ & $\mathrm{x}$ & & \\
\hline 7 & 105539 & hCG43758.3 & KRT8 & & $\mathrm{x}$ & & \\
\hline 8 & 184795 & hCG28316.3 & TIMP4 & & & & $\mathrm{x}$ \\
\hline 9 & 167511 & hCG27180.1 & GAL & $\mathrm{x}$ & $\mathrm{x}$ & & \\
\hline 10 & 157617 & hCG31814.2 & RAB34 & & & & $\mathrm{x}$ \\
\hline 11 & 199474 & hCG16335.3 & PCDH18 & & & & $\mathrm{x}$ \\
\hline 12 & 123810 & hCG1811406.1 & GABRB3 & & & & $\mathrm{x}$ \\
\hline 13 & 182404 & hCG37044.2 & GDF15 & & & & $\mathrm{x}$ \\
\hline 14 & 174736 & hCG1640612.3 & VGF & & & & $\mathrm{x}$ \\
\hline 15 & 110722 & hCG32054.3 & VSNL1 & & $\mathrm{x}$ & & \\
\hline 16 & 133924 & hCG37138.5 & DNMT3B & $\mathrm{x}$ & $\mathrm{x}$ & & \\
\hline 17 & 202882 & hCG14790.3 & BCAT1 & $\mathrm{x}$ & & & \\
\hline 18 & 235077 & hCG2021649 & SOX2 & $\mathrm{x}$ & $\mathrm{x}$ & & \\
\hline 19 & 208347 & & MT1H & $\mathrm{x}$ & & & \\
\hline 20 & 171539 & hCG21792.2 & MT1G & & & & $\mathrm{x}$ \\
\hline 21 & 207047 & hCG1640606.3 & HESX1 & $\mathrm{x}$ & & & \\
\hline 22 & 108203 & hCG37843.4 & FOXD1 & & & & $\mathrm{x}$ \\
\hline 23 & 159281 & hCG32831.4 & CCNA1 & & & $\mathrm{x}$ & \\
\hline 24 & 130276 & & PSG9 & & & & $\mathrm{x}$ \\
\hline 25 & 163073 & hCG1995680.1 & PSG9 & & & & $\mathrm{x}$ \\
\hline 26 & 186797 & hCG40422.3 & SOX17 & $\mathrm{x}$ & $\mathrm{x}$ & & \\
\hline 27 & 207413 & hCG22160.2 & KIT & $\mathrm{x}$ & $\mathrm{x}$ & & \\
\hline 28 & 180093 & hCG38608.2 & CDX1 & & & & $\mathrm{x}$ \\
\hline 29 & 161261 & hCG1781169.1 & HHEX & & & & $\mathrm{x}$ \\
\hline 30 & 132057 & hCG19120.4 & HIST1H2AC & & & & $\mathrm{x}$ \\
\hline 31 & 144265 & hCG1743060.2 & HIST1H2AL & & & & $\mathrm{x}$ \\
\hline 32 & 124744 & hCG15992.3 & EGR3 & & & & $\mathrm{x}$ \\
\hline 33 & 172634 & hCG1784453.2 & CYP2R1 & & & & $\mathrm{x}$ \\
\hline 34 & 126700 & hCG1770671.5 & ZNF382 & & & & $\mathrm{x}$ \\
\hline 35 & 189973 & hCG1984382.1 & OR1F1 & & & & $\mathrm{x}$ \\
\hline 36 & 201678 & hCG1784453.2 & CYP2R1 & & & & $\mathrm{x}$ \\
\hline 37 & 101762 & hCG73093.4 & PRAME & $\mathrm{x}$ & $\mathrm{x}$ & & \\
\hline 38 & 147920 & hCG26948.3 & CPEB1 & $\mathrm{x}$ & $\mathrm{x}$ & & \\
\hline 39 & 215855 & hCG29342.2 & PIP5K1B & & & & $\mathrm{x}$ \\
\hline 40 & 108125 & hCG2003451 & SPESP1 & & & & $\mathrm{x}$ \\
\hline 41 & 141060 & hCG19717.2 & KLHL10 & & & & $\mathrm{x}$ \\
\hline
\end{tabular}


DNA array analysis

In order to determine global gene-expression patterns, RNA was extracted from TCam-2 and JKT-1 cells, and DNA array analysis was performed comparing the two cell lines with normal germ cell tissue and material derived from GCT. Initially, unsupervised hierarchical clustering of seminomas, embryonal carcinomas, and normal tissues (UPGMA unweighted average, Euclidean distance) was performed by using Spotfire Decision Site for Functional Genomics (Spotfire, Europe, Göteborg, Sweden). This showed a convincing clustering of the samples into groups of the different entities. The two cell lines JKT-1 and TCam-2 clustered with the tumor samples, but no separation between seminoma and embryonal carcinoma was possible (not shown). The failure of the unsupervised cluster method with 32,878 transcripts to determine whether the cell lines were more closely related to seminoma or embryonal carcinoma might have been attributable to genes contributed by the tumor samples derived from the stroma and by an inflammatory infiltrate that were not present in cell culture samples. To overcome this, we used Panther (Celera Discovery systems) and the Gene ontology (GO) consortium database to identify and remove genes related to the immune response and unclassified genes. A significance analysis of microarrays (SAM 2.21; Tusher et al. 2001) was used to extract genes differentially expressed between seminoma and embryonal carcinomas.

Finally, a list of 41 probes (corresponding to 39 gene products, see Table 1) that were published and validated by ourselves and others (see Table 1) was used to perform a hierarchical cluster analysis and showed that TCam-2 clustered to the group of seminoma, whereas JKT-1 displayed an expression pattern related to embryonal carcinoma (Fig. 1f). Relative expression values of the 41 probes are shown in Supplemental Data S3.

\section{RT-PCR, Western blot, and immunohistochemistry}

In order to confirm the data generated by the DNA array analysis, we extracted RNA from TCam-2 and JKT- 1 cells and tested for the expression of the marker of pluripotency OCT3/4, the marker of seminomas AP- $2 \gamma$, AFP, PLAP, and MAGE-A4, the marker of spermatocytic seminoma (Fig. 2a). Bands for OCT3/4, AP-2 $\gamma$, and AFP could be detected in TCam-2 cells (Fig. 2a), whereas JKT-1 was positive for AFP and displayed only a weak signal for OCT3/4 and AP-2 $\gamma$ after application of an extended RT protocol (Fig. 2a, J(40)).

However, the detection of RNA does not necessarily indicate that the respective protein is being made. For example, miRNA might inhibit translation, or a short halflife of the message might result in reduced protein levels. a
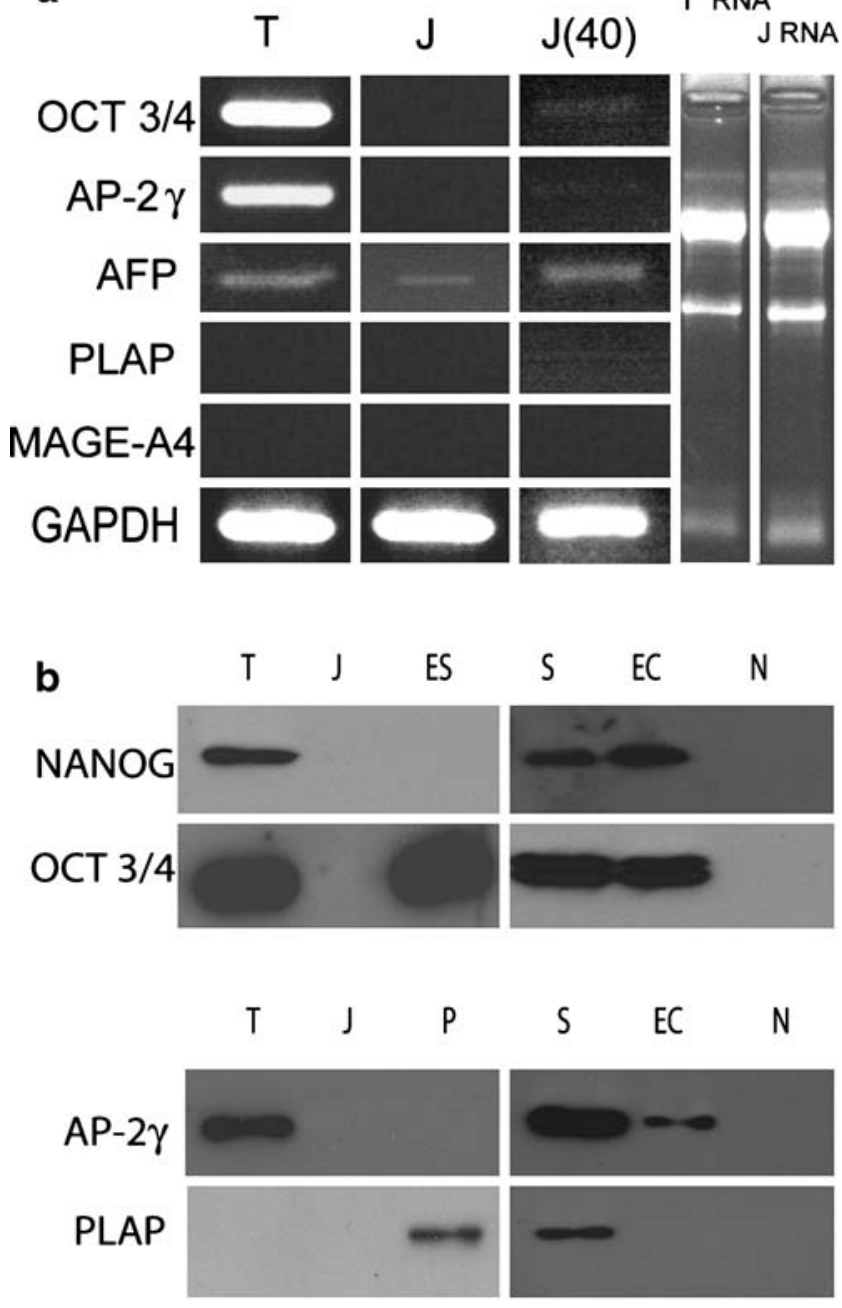

S EC N
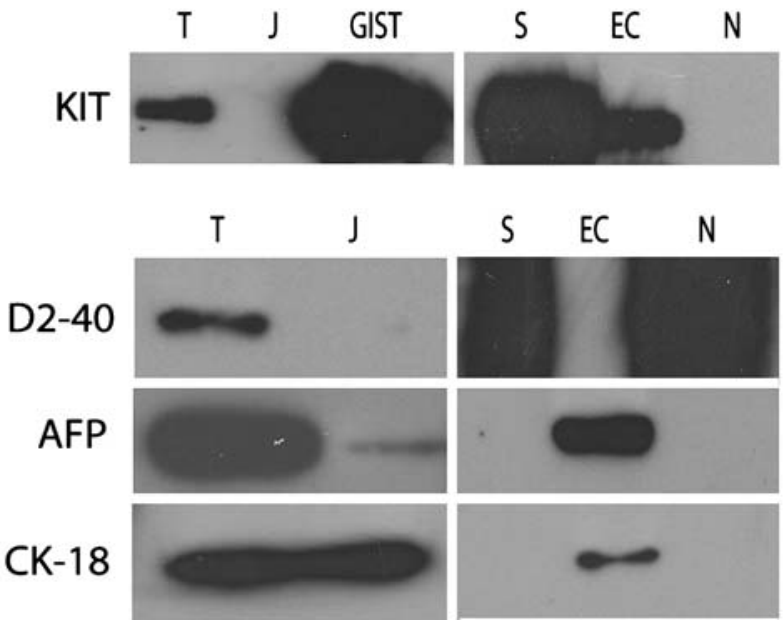

Fig. 2 a RT-PCR analysis of cDNA of TCam-2 $(T)$ and JKT-1 $(J)$ for expression of the genes indicated $(J(40)$ extended PCR protocol with 40 cycles). The gel to check for RNA quality is depicted right (T RNA, $J R N A$ ). b Western blot analysis of $20 \mu \mathrm{g}$ TCam-2 and JKT-1 proteins probed with the antibodies indicated left ( $T$ TCam-2, $J$ JKT-1, $S$ seminoma tissue, EC embryonal carcinoma, ES murine embryonic stem cells, $N$ normal testes tissue, $P$ placenta, GIST gastro-intestinal stroma tumour). $\beta$-actin expression was analysed as a loading control for each experiment (data not shown) 
Hence, we performed Western blot analyses in order to determine the protein levels of several marker genes upregulated in GCT. The markers of pluripotency NANOG and OCT $3 / 4$ and the transcription factor AP- $2 \gamma$, the receptor tyrosine kinase KIT, AFP, D2-40, and cytokeratin 18 (CK18) were expressed (Fig. 2b) In TCam-2 cells. On the other hand, only AFP and CK18 protein could be detected in JKT-1 cells (Fig. 2b).
TCam-2
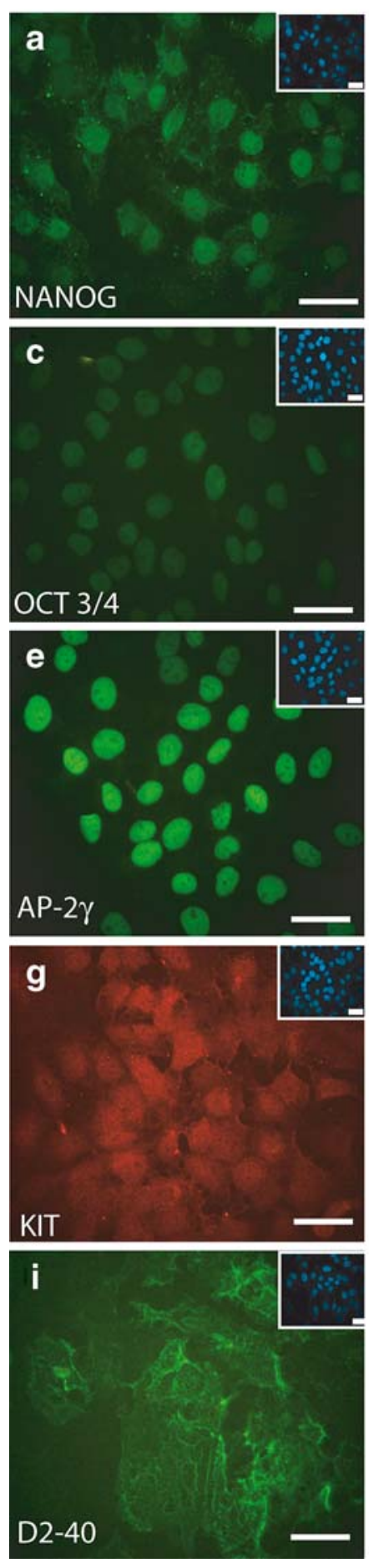

Fig. 3 Immunohistochemistry of TCam-2 (a, c, g, i, n, p) and JKT-1

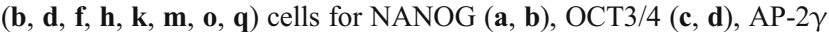
$(\mathbf{e}, \mathbf{f}), \operatorname{KIT}(\mathbf{g}, \mathbf{h}), \mathrm{D} 2-40(\mathbf{i}, \mathbf{k}), \operatorname{AFP}(\mathbf{l}, \mathbf{m}), \operatorname{CK}-18(\mathbf{n}, \mathbf{o}), \beta \mathrm{HCG}$

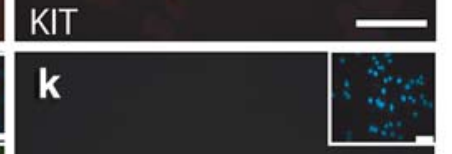

TCam-2
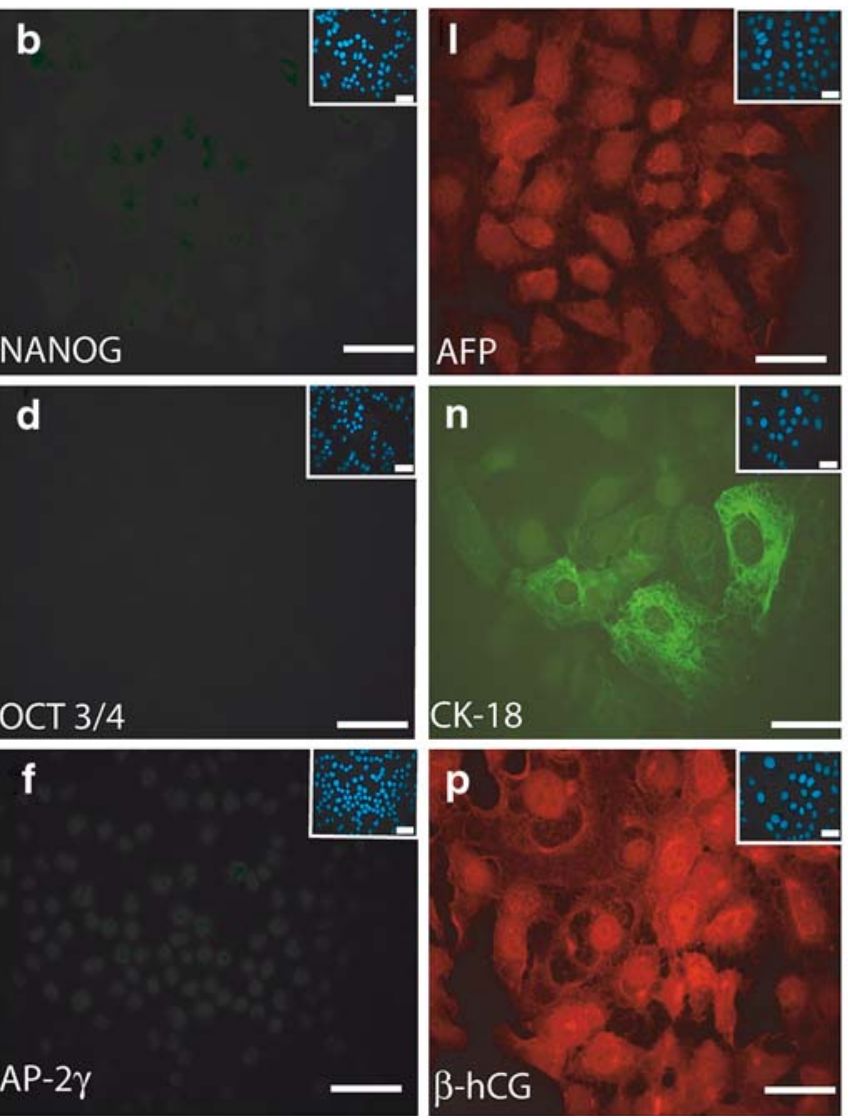

CK-18
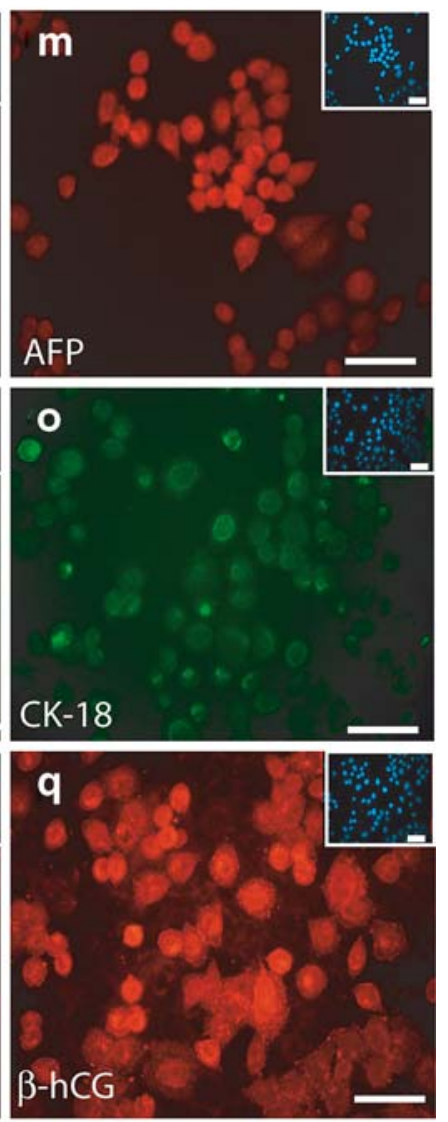

(p, q). Upper right insets: DAPI (4,6-diamidino-5-phenylindole) staining of the nuclei (blue). Bars $10 \mu \mathrm{m}$ 


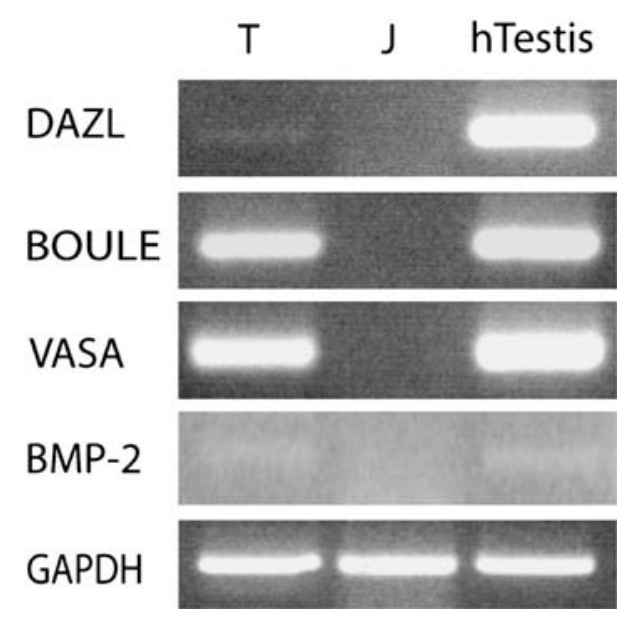

Fig. 4 RT-PCR analysis of cDNA of TCam-2 $(T)$ and JKT-1 $(J)$ cells and human testis (hTestis) for expression of genes indicated left

The results obtained by Western analysis were further corroborated by immunohistochemistry. Again, TCam-2 cells were positive for NANOG, OCT3/4, AP- $2 \gamma$, D2-40, AFP, and CK 18 (Fig. 3), whereas only AFP and CK18 could be detected in JKT-1 cells (Fig. 3). Interestingly, both cell lines were positive for $\beta \mathrm{HCG}$, a marker usually found in choriocarcinoma (Fig. 3p,q). Taken together, the data indicated that TCam-2 cells represented a seminoma-like phenotype, whereas the classification of JKT-1 required further analysis. Expression of AFP and CK-18 in JKT-1 suggested a yolk-saclike character of the cells. Korkola et al. (2006) reported that yolk-sac tumors displayed high levels of BMP-2 compared with other GCTs, thus serving as a classifier for this tumor entity. However, BMP-2 could not be detected in JKT-1 cells by using RT-PCR (Fig. 4, compare with TCam-2).

Since JKT-1 was negative for most of the GCT markers tested, we analyzed the levels of general germ cell markers VASA, DAZL, and BOULE via RT-PCR (Ezeh et al. 2005). Again, JKT-1 was negative, whereas TCam-2 was positive for these markers (Fig. 4).

\section{Discussion}

In vivo studies of material derived from tumors can provide insights regarding the complex genetic and cellular interactions of tumors. To address mechanistic issues of tumor behavior further, a simplified in vitro system is mandatory.

For seminoma (a subgroup of GCTs), many research groups including our own have failed to establish an appropriate cell line. Hence, to date, only two lines TCam-2 and JKT-1 have been derived from seminoma (Mizuno et al. 1993; Kinugawa et al. 1998). Where several laboratories have utilized mainly the JKT- 1 cell line (Jo et al. 1999; Hatakeyama et al. 2004; Kobayashi et al. 2004; Roger et al. 2004, 2005; Shiraishi et al. 2005) as a surrogate for seminoma, TCam-2 (Koshida et al. 2000; Kitazawa et al. 2006) had been used rarely. Since the cell lines were originally published, various novel marker genes have been described making the identification and classification of TGCTs more precise and powerful. In this study, we have performed a side-by-side comparison of the two cell lines and analyzed basic parameters, such as morphology and growth characteristics. Fundamental differences in cell adhesion and doubling time have become apparent, with TCam-2 growing more slowly (doubling time: $58 \mathrm{~h}$ ) compared with JKT-1 (doubling time: $27 \mathrm{~h}$ ), data that are in accordance with previous publications (Mizuno et al. 1993; Kinugawa et al. 1998).

In this study, we have used a whole-genome approach to compare the gene-expression profiles of TCam-2 and JKT-1 with those of samples from normal and testicular tumor tissue. The analysis has revealed that TCam- 2 clusters with the group of seminomas, whereas JKT-1 clusters with embryonal carcinomas. Of note, the dendrogram algorithm clusters the seminomas and the embryonal carcinomas together in two distinct groups, and the cell lines lie in their immediate neighborhood. This indicates that the cell lines are closely related to the respective tumor entity but not completely identical. This difference might also be attributed to the likelihood that the samples generated from tumors represent a mixture of tumor and normal tissue displaying a heterogeneity that cannot be modeled in cell culture systems. On the other hand, any cell that is taken out of its physiological context and placed into an in vitro culture system might adapt to its new environment and consequently change its expression profile, conserving only a part of its original expression pattern.

Further analysis with RT-PCR, Western blot, and immunohistochemistry has confirmed these findings. The original publication of the TCam-2 cell line did report its immunoreactivity with respect to 5G9 (an anti-testicularcancer monoclonal antibody) or 4B3 (PTHrP); here, we have extended the study to demonstrate the expression of OCT3/4, NANOG, AP- $2 \gamma$, KIT, CK18, VASA, DAZL, and D2-40 by using RT-PCR, Western blot, and/or immunohistochemistry, thereby adding further evidence to the seminomatous nature of TCam-2. However, in our hands, TCam-2 expresses AFP but not PLAP, whereas the original publication found the cells to be AFP-negative and PLAP-positive (Mizuno et al. 1993). This might be an indicative of a certain drift of the cell culture over the years in vitro from 1993 to present. Since some cells within a seminoma are known to be positive for AFP, a known marker for yolk-sac tumors, and since not every seminoma is positive for PLAP (Franke et al. 2000), these result do not impact on the overall suitability of TCam-2 as a cell culture model for seminoma. In addition, TCam-2 displays the characteristic gain of chromosomes $9 p$ and 
$12 \mathrm{p}$, as shown by comparative genomic hybridization (Goddard et al. 2007). Goddard et al. (2007) have also shown the expression of OCT3/4 and KIT in TCam-2 cells, further confirming our data. However, of note, TCam-2 cells express BOULE, which is usually detected in adult meiotic germ cells (Ezeh et al. 2005), and BHCG, a marker for choriocarcinoma, indicating a distinct difference in the gene-expression pattern of this cell line compared with that of seminoma cells in situ.

JKT-1, on the other hand, does not cluster to seminomas but rather seems to group with embryonal carcinomas. Like TCam-2, JKT-1 was originally reported to be AFP-negative and PLAP-positive but has been found here to be AFPpositive and PLAP-negative. Furthermore, JKT-1 lacks expression of KIT and displays low levels of AP- $2 \gamma$. Since these markers discriminate between seminoma (AP- $2 \gamma+$ and $\mathrm{KIT}+$ ) and non-seminoma (AP- $2 \gamma$ low, KIT-; HoeiHansen et al. 2004; Almstrup et al. 2005b; Pauls et al. 2005), JKT-1 cannot represent a seminoma-like cell type.

Moreover, our Western blot and immunohistochemical data have revealed a lack of expression of NANOG, OCT3/ 4, and D2-40 in JKT-1 cells. Lack of pluripotency markers and the absence of PLAP and KIT expression has been reported for a rare GCT predominantly found in older patients, viz., the spermatocytic seminoma (Rajpert-De Meyts et al. 2003). However, JKT-1 lacks expression of MAGE-A4, a marker characteristic for this type of seminoma (Rajpert-De Meyts et al. 2003). We have been able to obtain a weak band for OCT3/4 indicative of low expression by using an extended RT protocol (40 cycles instead of 35 cycles), and one can argue that the expression of the OCT3/4 gene might have fallen below the detection threshold of Western blot and immunohistochemistry. Since low levels of OCT3/4 and NANOG have been reported in yolk sac tumors and choriocarcinoma (Korkola et al. 2005), we have investigated whether JKT-1 displays increased levels of BMP-2, a genetic classifier for yolk-sac tumors (Korkola et al. 2005). However, JKT-1 shows no signal for BMP-2 either, also excluding this possibility. We further demonstrate that JKT-1 lacks expression of the germ cell markers DAZL (Lifschitz-Mercer et al. 2002) BOULE, and VASA (Ezeh et al. 2005), raising the question as to whether JKT-1 can be regarded as a GCT line at all. Hence, the data presented here suggest that JKT-1, although initially clustering to embryonal carcinomas, does not express a convincing set of markers indicative for GCTs and germ cells. Recent data published by Jong et al. (2007) further strengthen this notion. Experiments with JKT-1 as a model system for seminomas must therefore be undertaken with an awareness of these apparent discrepancies.

In summary, these analyses clearly show that the TCam-2 should be preferred over JKT-1 whenever a cell line with a seminoma-like nature is required.
Acknowledgements We thank Dr. Janet Shipley (Institute of Cancer Research, Sutton, England) for the TCam-2 cells, Dr. Michiko Fukuda (The Burnham Institute, La Jolla, Calif.) for the JKT-1 cells, and Dr. F. Honecker (Hamburg University Medical Center, Department of Oncology/Hematology, Hamburg, Germany) for the EC cell line 2102EP. The skilful technical assistance of Susanne Steiner and of Volker Böhnert during his "MBM Wahlmodul" is gratefully acknowledged.

\section{References}

Adami HO, Bergstrom R, Mohner M, Zatoński W, Storm H, Ekbom A et al (1994) Testicular cancer in nine northern European countries. Int J Cancer 59:33-38

Almstrup K, Ottesen AM, Sonne SB, Hoei-Hansen CE, Leffers H, Rajpert-De Meyts E et al (2005a) Genomic and gene expression signature of the pre-invasive testicular carcinoma in situ. Cell Tissue Res 322:159-165

Almstrup K, Hoei-Hansen CE, Nielsen JE, Wirkner U, Ansorge W, Skakkebaek NE et al (2005b) Genome-wide gene expression profiling of testicular carcinoma in situ progression into overt tumours. Br J Cancer 92:1934-1941

Biermann K, Heukamp LC, Steger K, Zhou H, Franke FE et al (2007) Genome-wide expression profiling reveals new insights into pathogenesis and progression of testicular germ cell tumors. Cancer Genomics Proteomics (in press)

Ezeh UI, Turek PJ, Reijo RA, Clark AT (2005) Human embryonic stem cell genes OCT4, NANOG, STELLAR, and GDF3 are expressed in both seminoma and breast carcinoma. Cancer 104:2255-2265

Franke FE, Pauls K, Kerkman L, Steger K, Klonisch T, Metzger R et al (2000) Somatic isoform of angiotensin I-converting enzyme in the pathology of testicular germ cell tumors. Hum Pathol 31:1466-1476

Goddard NC, McIntyre A, Summersgill B, Gilbert D, Kitazawa S, Shipley J (2007) KIT and RAS signalling pathways in testicular germ cell tumours: new data and a review of the literature. Int J Androl 30:337-349

Hatakeyama S, Ohyama C, Minagawa S, Inoue T, Kakinuma H, Kyan A et al (2004) Functional correlation of trophinin expression with the malignancy of testicular germ cell tumor. Cancer Res 64:4257-4262

Hoei-Hansen CE, Nielsen JE, Almstrup K, Sonne SB, Graem N, Skakkebaek E et al (2004) Transcription factor AP-2gamma is a developmentally regulated marker of testicular carcinoma in situ and germ cell tumors. Clin Cancer Res 10:8521-8530

Jager R, Werling U, Rimpf S, Jacob A, Schorle H (2003) Transcription factor AP-2gamma stimulates proliferation and apoptosis and impairs differentiation in a transgenic model. Mol Cancer Res 1:921-929

Jo Y, Kinugawa K, Matsuki T, Morioka M, Tanaka H (1999) Analysis of the biological properties and use of comparative genomic hybridization to locate chromosomal aberrations in the human testicular seminoma cell line JKT-1 and its highly metastatic cell line JKT-HM. BJU Int 83:469-475

Jong J de, Stoop H, Gillis AJ, Gurp RJ van, Drunen E van, Beverloo $\mathrm{HB}$ et al (2007) JKT-1 is not a human seminoma cell line. Int J Androl 30:350-365

Kinugawa K, Hyodo F, Matsuki T, Jo Y, Furukawa Y, Ueki A et al (1998) Establishment and characterization of a new human testicular seminoma cell line, JKT-1. Int J Urol 5:282-287

Kitazawa S, Takenaka A, Kondo T, Mizoguchi A, Kitazawa R (2006) Protruding disordered loop of $\mathrm{gClqR}$ is specifically exposed and 
related to antiapoptotic property in germ cell lineage. Histochem Cell Biol 126:665-677

Kobayashi T, Fujii T, Jo Y, Kinugawa K, Fujisawa M (2004) Possible mechanism responsible for the acquisition of resistance to cisdiamminedichloroplatinum (II) by cultured human testicular seminoma cells. J Urol 171:1929-1933

Korkola JE, Houldsworth J, Dobrzynski D, Olshen AB, Reuter VE, Bosl GJ et al (2005) Gene expression-based classification of nonseminomatous male germ cell tumors. Oncogene 24: $5101-5107$

Korkola JE, Houldsworth J, Chadalavada RS, Olshen AB, Dobrzynski D, Reuter VE et al (2006) Down-regulation of stem cell genes, including those in a $200-\mathrm{kb}$ gene cluster at $12 \mathrm{p} 13.31$, is associated with in vivo differentiation of human male germ cell tumors. Cancer Res 66:820-827

Koshida K, Konaka H, Kato H, Miyagi T, Egawa M, Uchibayashi T et al (2000) [Correlation between expression of metastasis-related genes and lymph node metastasis in testicular cancer]. Hinyokika Kiyo 46:775-781

Lifschitz-Mercer B, Elliott DJ, Issakov J, Leider-Trejo L, Schreiber L, Misonzhnik F et al (2002) Localization of a specific germ cell marker, DAZL1, in testicular germ cell neoplasias. Virchows Arch 440:387-391

Looijenga LH, Oosterhuis JW (2002) Pathobiology of testicular germ cell tumors: views and news. Anal Quant Cytol Histol 24: 263-279

Mizuno Y, Gotoh A, Kamidono S, Kitazawa S (1993) [Establishment and characterization of a new human testicular germ cell tumor cell line (TCam-2)]. Nippon Hinyokika Gakkai Zasshi 84: $1211-1218$

Muller-Tidow C, Diederichs S, Schrader MG, Vogt U, Miller K, Berdel WF et al (2003) Cyclin A1 is highly expressed in aggressive testicular germ cell tumors. Cancer Lett 190:89-95

Okada K, Katagiri T, Tsunoda T, Mizutani Y, Suzuki Y, Kamada M et al (2003) Analysis of gene-expression profiles in testicular seminomas using a genome-wide cDNA microarray. Int J Oncol 23:1615-1635

Oosterhuis JW, Looijenga LH (2005) Testicular germ-cell tumours in a broader perspective. Nat Rev Cancer 5:210-222

Pauls K, Jager R, Weber S, Wardelmann E, Koch A, Büttner R et al (2005) Transcription factor AP-2gamma, a novel marker of gonocytes and seminomatous germ cell tumors. Int $\mathrm{J}$ Cancer $115: 470-477$
Peitz M, Jager R, Patsch C, Jager A, Egert A, Schorle H et al (2007) Enhanced purification of cell-permeant Cre and germline transmission after transduction into mouse embryonic stem cells. Genesis 45:508-517

Rajpert-De Meyts E, Jacobsen GK, Bartkova J, Aubry F, Samson M, Bartek J et al (2003) The immunohistochemical expression pattern of Chk2, p53, p19INK4d, MAGE-A4 and other selected antigens provides new evidence for the premeiotic origin of spermatocytic seminoma. Histopathology 42:217-226

Roger C, Mograbi B, Chevallier D, Michiels JF, Tanaka H, Segretain D et al (2004) Disrupted traffic of connexin 43 in human testicular seminoma cells: overexpression of $\mathrm{Cx} 43$ induces membrane location and cell proliferation decrease. J Pathol 202:241-246

Roger C, Lambard S, Bouskine A, Mograbi B, Chevallier D, Nebout $M$ et al (2005) Estrogen-induced growth inhibition of human seminoma cells expressing estrogen receptor beta and aromatase. J Mol Endocrinol 35:191-199

Shiraishi T, Yoshida T, Nakata S, Horinaka M, Wakada M, Mitzutani $Y$ et al (2005) Differential response at the hGABP/E4TF1 site of retinoblastoma gene promoter in human testicular seminoma cells. Oncol Rep 13):871-874

Skakkebaek NE (1972) Possible carcinoma-in-situ of the testis. Lancet II:516-517

Skakkebaek NE (1978) Carcinoma in situ of the testis: frequency and relationship to invasive germ cell tumours in infertile men. Histopathology 2:157-170

Skotheim RI, Monni O, Mousses S, Fossa SD, Kallioniemi OP, Lothe RA et al (2002) New insights into testicular germ cell tumorigenesis from gene expression profiling. Cancer Res 62:2359-2364

Skotheim RI, Lind GE, Monni O, Nesland JM, Abeler VM, Fosså SD et al (2005) Differentiation of human embryonal carcinomas in vitro and in vivo reveals expression profiles relevant to normal development. Cancer Res 65:5588-5598

Sugimura J, Foster RS, Cummings OW, Kort EJ, Takahashi M, Lavery TT et al (2004) Gene expression profiling of early- and late-relapse nonseminomatous germ cell tumor and primitive neuroectodermal tumor of the testis. Clin Cancer Res 10: $2368-2378$

Tusher VG, Tibshirani R, Chu G (2001) Significance analysis of microarrays applied to the ionizing radiation response. Proc Natl Acad Sci USA 98:5116-5121 